\title{
Corn Stover Ethanol Yield as Affected by Grain Yield, Bt Trait, and Environment
}

Pavani Tumbalam ${ }^{\mathrm{a}}$, Kurt D. Thelen ${ }^{\mathrm{a} *}$, Andrew Adkins ${ }^{\mathrm{a}}$, Bruce Dale $^{\mathrm{b}}$, Venkatesh Balan ${ }^{\mathrm{b}}$, Christa Gunawan $^{\mathrm{b}}$, Juan Gao ${ }^{\mathrm{a}, 1}$

${ }^{a}$ Plant, Soil and Microbial Sciences Department, Michigan State University, 1066 Bogue St., East Lansing 48824. ${ }^{\mathrm{b} B i o m a s s}$ Conversion Research Laboratory, Department of Chemical Engineering and Material Science, Michigan State University, 3900 Collins Road, University Corporate Research Complex, Lansing, MI 48910, *Corresponding author (517-355-0271, thelenk3@msu.edu).

${ }^{1}$ Nanjing Institute of Soil Science, Chinese Academy of Sciences, 71 East Beijing Road, Nanjing, P.R.China 210008.

\section{Abbreviations}

Bt: Bacillus thuringiensis

AFEX: Ammonia Fiber Expansion

NREL: National Renewable Energy Laboratory

EtOH: Ethanol

ASE: Accelerated Solvent Extractor

SRS: Sugar Recovery Standards

ABSL: Acetyl Bromide Soluble Lignin

(C) 2015. This manuscript version is made available under the Elsevier user license http://www.elsevier.com/open-access/userlicense/1.0/ 
SHF: Separate Hydrolysis and Fermentation 


\begin{abstract}
Literature values for glucose release from corn stover are highly variable which would likely result in tremendous variability in bio-refinery ethanol yield from corn stover feedstock. A relatively recent change in United States corn genetics is the inclusion of the Bacillus thuringiensis $(\mathrm{Bt})$ trait, which now accounts for three-fourths of all US planted corn acreage. The objective of this study was to evaluate the effect of corn grain yield, inclusion of the Bt trait, and location environment on corn stover quality for subsequent ethanol conversion. Two hybrid pairs (each having a Bt and non-Bt near-isoline) were analyzed giving a total of 4 hybrids. In 2010 and 2011, field plots were located in Michigan at four latitudinal differing locations in four replicated plots at each location. Stover composition and enzymatic digestibility was analyzed and estimated ethanol yield $\left(\mathrm{g} \mathrm{g}^{-1}\right)$ was calculated based on hydrolysable glucan and xylan levels. Analysis showed that there were no significant differences in total glucose or xylose levels nor in enzymatically hydrolysable glucan and xylan concentrations between Bt corn stover and the nonBt stover isolines. Regression analyses between corn grain yield $\left(\mathrm{Mg} \mathrm{ha}^{-1}\right)$ and corn stover ethanol yield $\left(\mathrm{g} \mathrm{g}^{-1}\right)$ showed an inverse relationship indicative of a photosynthate source-sink relationship. Nevertheless, the quantity of stover produced was found to be more critical than the quality of stover produced in maximizing potential stover ethanol yield on a land area basis.
\end{abstract}

Keywords: Biofuels, corn stover, Bt trait, bioethanol, lignocellulosic ethanol, bioenergy. 


\section{Introduction}

Corn stover, composed of stalks, leaves and cobs after grain is harvested, has been identified as the most abundant agricultural crop residue available in the Midwest and it is expected to be a primary source of bioethanol cellulosic feedstock with the production of about 200 million $\mathrm{Mg}$ per year [1, 2, and 3]. Technology for producing biofuels (such as ethanol, butanol, or various hydrocarbons) and biobased chemicals from lignocellulosic material is experiencing significant advances in an effort to meet global energy and chemical needs [4, 5]. Examples of lignocellulosic biomass materials considered as feedstocks for bioethanol production include crop residues such as corn stover and wheat straw, woody residues from forest thinning and paper production, cool- and warm-season grasses such as switchgrass and fescue, and crops such as sorghum [6]. Lignocellulosic ethanol is predicted to have a favorable greenhouse gas profile, alleviate dependence on foreign oil, compensate for decreasing worldwide petroleum reserves, and provide an economic boost to rural communities [7]. The importance of cellulosic biomass as a renewable energy resource has increased with the anticipated shortage of fossil reserves and increased air pollution [8].

Total stover biomass produced in corn is generally at a 1:1 mass ratio with grain production $[9,10]$. However, the amount of corn stover available to harvest is dependent on many factors including: total biomass produced; weather and field conditions at harvest; harvest equipment shortcomings; and, the grower's management bias for retaining some stover biomass in the field for environmental and agronomic reasons [11]. The composition of corn stover has been shown to be highly variable. Factors such as harvest year, environment, and variety result in glucose, lignin, or xylose values ranging up to $10 \%$ on an absolute basis [12]. Location and genotype 
could also play significant roles in the biomass composition and ethanol yield of corn stover. A recent publication from Banerjee et al.[13], reported differences in corn stover glucose release ranging from 64 to $95 \%$. These significant differences in fermentable glucose levels would likely result in tremendous variability in bio-refinery ethanol yield from corn stover feedstock.

Currently, $76 \%$ of corn stover produced in the U.S. is derived from plants containing a Bt transgene [14]. The Bt transgene originates from Bacillus thuringiensis, a naturally occurring soil bacterium that produces proteins $(\mathrm{Bt})$ toxic to specific target insects. Plants genetically modified to produce the Bt protein have a built-in larvicidal toxin that kills lepidopteran pests, especially the European corn borer (Ostrinia nubilalis), a major pest in Europe and North America that can reduce yields of corn by 3-7\% per borer, [15]. Work published by Saxena and Stotzky in 2001 [16] showed that the lignin content, an anti-quality agent for ethanol production was significantly higher (33-97\% higher) for Bt lines compared to their respective non-Bt isoline.

The objective of this study was to evaluate the effect of corn grain yield, Bt trait, and location environment on corn stover quality for subsequent ethanol conversion.

\section{Materials and methods}

\subsection{Sample collection}

Corn was grown on four farms located in Ingham, Menominee, Mason, and Saginaw counties all located in Michigan in 2010 and 2011. The latitude and longitude of the research locations within Ingham, Mason, Menominee and Saginaw counties were 42*38'08.31’N and $84^{*} 13^{\prime} 32.37^{\prime \prime} \mathrm{W} ; 43^{*} 57^{\prime} 40.37^{\prime \prime} \mathrm{N}$ and $86^{*} 09^{\prime} 28.92^{\prime \prime} \mathrm{W} ; 45^{*} 27^{\prime} 01.27^{\prime \prime} \mathrm{N}$ and $87^{*} 35^{\prime} 33.033^{\prime} \mathrm{W}$ and 
$43^{*} 07^{\prime} 55.66$ ” $\mathrm{N}$ and $83^{*} 58^{\prime} 04.65^{\prime}$ 'W respectively. Two hybrid pairs, one $\mathrm{Bt}$ and one near-isoline relative were analyzed giving a total of 4 hybrids with the specific hybrid pairs grown at each respective location (Table 1). The field plots were managed consistent with the Michigan State University, Corn Hybrid Testing Program [17] and information on the soils present at each research location is shown in Table 2. Soil samples were taken at time of planting and soil conditions were observed and testing was completed by the Michigan State University soil and plant nutrient laboratory. Fertilizers (Nitrogen, Phosphorous and Potassium) were applied in all the four locations at different application rates (Table 3). Hybrids were planted from mid-May to early June and harvested from mid-October to early November depending upon location (Table 3). Previous crop planted in 2010 at Ingham was soybean, carrots at Mason, alfalfa in Menominee, and corn in Saginaw. In 2011 previous crops were soybeans for Ingham and Saginaw locations and corn for Mason and Menominee. At each location, the entire corn plants in the two $1 \mathrm{~m}$ sections taken from the center two rows of a 4 row plot for each selected hybrid were hand harvested, cut approximately $15 \mathrm{~cm}$ above ground level, bagged, and labeled by individual plot. Stover and cob fractions were dried at $65^{\circ} \mathrm{C}$ with forced air and ground to $1 \mathrm{~mm}$ and grain was air dried at room temperature. The experiment was replicated four times for every treatment at each location. The ears from the plants were removed and the grain from the cob was shelled. Wet and dry weights were recorded from all three fractions for each plot (stover, cob, and grain). The grain was discarded after recording dry matter yields. Stover and cob fractions were all ground through a 1-mm sieve and stored in labeled quart size zip-lock bags. The dried ground samples were stored at $4^{\circ} \mathrm{C}$ previous to analytical processing. The total number of stover biomass samples collected for this study was 104 combining both the 2010 and 2011 years. 


\subsection{Composition analysis}

Composition of the untreated corn stover samples was determined by following the procedures developed by the National Renewable Energy Laboratory (NREL) for determination of extractives [18] and structural carbohydrates [19]. Analysis was performed in triplicate for each sample. Ground sample ( $1 \mathrm{~g})$ was used for total oil extraction by accelerated solvent extractor ASE 200 (Dionex, Idstein, Germany) equipped with an $11 \mathrm{ml}$ stainless steel extractor cell. The following conditions were set on the ASE system: preheat for $6 \mathrm{~min}$, heat for $6 \mathrm{~min}$, oven temperature at $105^{\circ} \mathrm{C}$, static time for $10 \mathrm{~min}$, flush volume $70 \%$, and purge time for $60 \mathrm{~S}, 2$ static cycles, and extraction pressure at 1000psi. After process, extraction solvent hexane was evaporated by purging oxygen free compressed nitrogen (AGA gas) above the surface. Moisture content analysis was performed to determine the dry weight of the corn stover using an A \& D Moisture analyzer, MX-50 (Milpita, CA). Polysaccharide content assays were run in triplicates in 100ml autoclavable high-pressure tube (Chemglass Life Science Inc., Vineland, NJ). Extracted corn stover $(0.3 \mathrm{~g})$ and $37 \mathrm{ml} 72 \%(\mathrm{w} / \mathrm{w})$ sulfuric acid were added in to the tube and after continuous shaking for 1 hour in a shaker at $32^{\circ} \mathrm{C}, 84 \mathrm{ml}$ distilled water was added and then the tubes were autoclaved at $121^{\circ} \mathrm{C}$ for 1 hour. Filtered hydrolysate samples were run on HPLC to analyze the sugars (as described in the HPLC analysis section of this paper) along with the sugar recovery standards (For $100 \mathrm{~mL}$ solution, $0.4 \mathrm{~g}$ glucose, $0.2 \mathrm{~g}$ xylose, and $0.08 \mathrm{~g}$ arabinose is added). All samples were analyzed in triplicate to ensure the quality of the composition levels.

Lignocellulosic isolate from each sample was weighed out into triplicate, $2 \mathrm{mg}$ technical replicates which were assayed using the acetyl bromide soluble lignin (ABSL) method [20]. The 
ABSL method was performed by treating cell wall material with a $25 \%$ (v/v) solution of acetyl bromide in glacial acetic acid under gentle heating conditions to solubilize the lignin matrix. The solubilized lignin was volumetrically diluted with glacial acetic acid and assayed using a photospectrometer at $280 \mathrm{~nm}$ (Spectromax 384 plus). For the lignin content calculation, the molar extinction coefficient for maize $\left(17.75 \mathrm{~L} \mathrm{~g}^{-1} \mathrm{~cm}^{-1}\right)$ was used, which was previously determined in literature. The lignin composition analysis was performed using the thioacidolysis method, which is utilized to detect the p-Hydroxylphenyl (H), Guaiacyl (G), and Syringyl (S) monomers incorporated in the lignin matrix via $\beta-O-4$ ether linkages. Using the dried and isolated lignocellulosic material, three $2 \mathrm{mg}$ replicates were weighed into glass vials and heated with a mixture of dioxane, ethanethiol, and boron trifluoride diethyl etherate to liberate the lignin monomers. The extracted thioether derivatized monomers were subsequently silylated with BSA and quantitated using GC-MS analysis (Agilent 7890A / 5975C MS) according to the published procedure [20].

\subsection{Ammonia Fiber Expansion Pretreatment (AFEX)}

AFEX is a thermochemical process for pretreating biomass to decrystallize lignocellulose structure by removing hemicellulose and reducing lignin content. AFEX pretreatment was performed on individual corn stover samples as described by Bals et al. in 2010 [21], using 22$\mathrm{mL}$ stainless steel reactors heated in a metal heating block. Samples for high solid loading enzymatic hydrolysis were pretreated using a 300-mL stainless steel Parr reactor heated in a heating mantle. The AFEX conditions used for all samples were $0.6 \mathrm{~g} \mathrm{H}_{2} \mathrm{O} / \mathrm{g}$ dry sample, $1 \mathrm{~g}$ $\mathrm{NH}_{3} / \mathrm{g}$ dry sample, residence time $30 \mathrm{~min}$, and temperature $100^{\circ} \mathrm{C}$. Biomass was removed and dried in a fume hood overnight. After AFEX treatment, enzymatic hydrolysis was conducted 
where sugar monomers such as glucose and xylose were released for fermentation in conversion to ethanol. AFEX-pretreated samples were tested for effectiveness by performing enzymatic hydrolysis in duplicate. The samples were loaded into 20 -mL scintillation vials at $1 \%$ (w/v) glucan loading with working volume of $15 \mathrm{~mL}$. The hydrolysis was performed at $\mathrm{pH} 4.8$ using $50 \mathrm{mM}$ sodium citrate buffer for 72 hours in the incubator shaker (New Brunswick Scientific, Enfield, CT) at $50^{\circ} \mathrm{C}$ with agitation speed of $250 \mathrm{rpm}$. Sodium azide was added at concentration of $0.5 \mathrm{mM}$ to prevent microbial growth. The enzymes, CTec2 (Novozymes, Denmark), HTec2 (Novozymes, Denmark), and Multifect Pectinase (Genencor Inc, USA) were added at 10, 2.5, and $2.5 \mathrm{mg}$ protein per g glucan, respectively. To inhibit bacteria growth $40 \mathrm{mg} / \mathrm{L}$ tetracycline was added. Enzymes were deactivated by heating samples to $99^{\circ} \mathrm{C}$. Monomeric glucose and xylose concentrations were determined by analyzing $1 \mathrm{ml}$ of the filtered sample through HPLC. All hydrolysis samples were run in triplicates.

\subsection{Enzymatic hydrolysis}

For determination of cellulosic conversion to fermentable glucan and xylan enzymatic hydrolysis of AFEX pretreated corn stover samples was conducted at $6 \%(\mathrm{w} / \mathrm{w})$ glucan loading of $50 \mathrm{~g}$ total weight in $125-\mathrm{mL}$ Erlenmeyer flask for 96 hours at $250 \mathrm{rpm}$ and $50^{\circ} \mathrm{C}$. The enzymes, CTec2 (Novozymes, Denmark), HTec2 (Novozymes, Denmark), and Multifect Pectinase (Genencor Inc, USA), were added at 20,5 , and $5 \mathrm{mg}$ protein per g glucan, respectively. The $\mathrm{pH}$ of hydrolysis reaction was maintained at 4.8 using $12.1 \mathrm{M} \mathrm{HCl}$. At the completion of hydrolysis, the slurry was centrifuged at $14000 \mathrm{rpm}$ for $30 \mathrm{~min}$ to collect the hydrolysate which will be used for the subsequent fermentation experiment. The $\mathrm{pH}$ of hydrolysates were adjusted to 5.5, then they were sterile filtered using Stericup through $0.22 \mu \mathrm{m}$ membrane. Hydrolysate flasks were tightly 
sealed with rubber stoppers and secured with tape before being placed in an incubator set at $50^{\circ} \mathrm{C}$ at $250 \mathrm{rpm}$ for 5 hours. After the temperature in the flasks reached $50^{\circ} \mathrm{C}$, the flasks were removed and the remaining biomass was added and the enzymes were added based on the glucan content and the $\mathrm{pH}$ was re-checked. Hydrolysis was continued at $50^{\circ} \mathrm{C}$ for four days after which the hydrolysate was harvested by centrifugation at $14,000 \mathrm{rpm}$ for 30 minutes to remove unhydrolysate solids. Hydrolysate was sterile filtered through a $0.22 \mu \mathrm{m}$ filter and stored at $4{ }^{\circ} \mathrm{C}$ for subsequent fermentation. Hydrolysate samples for HPLC were prepared by diluting the samples 10 fold. Total volume of up to $100 \mathrm{ml}$ Deionized water was added to the pelleted unhydrolyzed solids in centrifuge bottles and by washing the flasks. For HPLC, $1 \mathrm{ml}$ of the hydrolysate was centrifuged and filtered through $0.22 \mu \mathrm{m}$ syringe Millipore filter.

\subsection{Estimated ethanol yield}

Ethanol yield was calculated based on the empirically derived compositional data and enzymatic hydrolysis yields as described above. The formula for estimated ethanol yield was as follows: $(([\mathrm{Glc}] \times \mathrm{Glc}$ conv $)+([\mathrm{Xyl}] \times \mathrm{Xyl}$ conv $)) * 51.1 \% *$ metabolic yield $=\left(\mathrm{EtOH} \mathrm{g} \mathrm{g}^{-1}\right.$ of stover dry matter)

[Glc] $=$ Total whole plant glucose expressed as g/dry g of biomass .

$[\mathrm{Xyl}]=$ Total whole plant $\mathrm{xylose}$ expressed as g/dry g of biomass.

Glc Conv- Percent total glucan converted into glucose under enzymatic hydrolysis. This was obtained from $1 \%$ glucan hydrolysis screening.

Xyl Conv- Percent total xylan converted into glucose under enzymatic hydrolysis. This was obtained from $1 \%$ xylan hydrolysis screening.

$51.1 \%$ - Maximum molar mass conversion of sugars to ethanol via fermentation. 
Metabolic Yield- Equals to the ratio of ethanol to the consumed sugars in the fermentation process [22]. A metabolic yield value of $93.1 \%$ was used as determined using a separate hydrolysis and fermentation (SHF) process for corn stover and yeast fermentation efficiency [23]. To estimate ethanol production on a land area basis, total stover produced was assumed to be equivalent to a 1:1 mass ratio with the measured corn grain yield as described by Graham et al [10]. Harvestable corn stover yield was calculated as 50\% of total stover produced, which was determined by Shinner et al. [11] to be the harvest efficiency expected for baling stover immediately after corn grain harvest. Harvestable corn stover was then multiplied by the ethanol yield ( $\mathrm{g} / \mathrm{dry} \mathrm{g}$ of biomass) as described above to determine ethanol production $\left(1 \mathrm{ha}^{-1}\right)$ on a land area basis.

\subsection{Statistical analysis}

Data were analyzed with the analysis of variance (ANOVA) using the PROC MIXED procedure, and PROC REG in SAS 9.4. Bt trait, hybrid pair, and location were held as fixed variables and year was considered random. Mean separation between variables was obtained by an LSD test, with effects considered significant at $\mathrm{P}<0.05$.

\section{Results and discussion}

At the Menominee location the 2010/11 growing seasons tended to be cooler than the Ingham, Mason and Saginaw locations when compared to the 30-year mean temperature (Fig 1). The Ingham location had a higher amount of precipitation while Mason and Saginaw had low precipitation when compared to their respective 30 year average precipitation levels. 
Location had a significant effect on xylose, glucose, hydrolysable xylan, hydrolysable glucan, and lignin (Table 4). Corn stover harvested at Menominee had significantly higher xylose levels than stover harvested from the Mason and Ingham locations (Table 5). The stover harvested at the Saginaw location had xylose levels consistent with all other locations. With regard to enzymatically hydrolysable levels of xylan, the Saginaw location stover had lower levels than the Mason stover. Stover harvested at the Ingham and Menominee locations had enzymatically hydrolysable levels of xylan consistent with stover harvested at all locations. Corn stover glucose levels were lowest at the Mason location, with enzymatically hydrolysable glucose levels lowest at the Menominee location. Lignin levels in the Saginaw stover were lower than lignin levels in stover harvested at Ingham and Menominee. In general, location was found to have the greatest effect on corn stover composition relative to the other experimental variables of hybrid and $\mathrm{Bt}$ trait. These findings are consistent with the highly variable corn stover glucose levels reported by Banerjee et al., in 2010 [24]. The absence of a Bt trait effect on lignin levels conflicts with results reported by Saxena and Stotzky in 2001 [12] which showed significantly higher lignin levels in Bt stover. However, our corn stover lignin results support those of Faust in 1999 [25] who reported no significant differences in lignin content between the dried biomass of whole plants of $\mathrm{Bt}$ and non-Bt corn. Furthermore, our finding of no $\mathrm{Bt}$ trait $\mathrm{x}$ hybrid pair interaction suggests that neither the Cry $1 \mathrm{AB}$ or combination of the Cry $1 \mathrm{AB}+$ mCry 3 events adversely affect corn stover quality with regard to estimated lignocellulosic ethanol yield. Our findings of no significant Bt trait effect on corn stover lignin, hydrolysable glucan, hydrolysable xylan levels is important to the future of the lignocellulosic ethanol industry that will rely heavily upon available corn stover [26] of which an estimated 76\% of US corn acreage was planted to Bt corn in the 2013 growing season [14]. 
The particular hybrid grown had a significant effect on glucose and lignin levels (Table 4). The Bayside hybrid (Relative maturity $=90$ days) had higher levels of glucose, an ethanol quality component, and lignin an ethanol anti-quality component compared to glucose and lignin levels found in the Nutech hybrid (Relative maturity = 104 days) (Table 7). This result is consistent with results reported by Lewis et al., [27] who found significant corn stover glucose and lignin differences between testcrosses of two recombinant inbreds. Similarly, Muttonni et al., [28] reported significant variation of stover glucose and pentose levels among four different maize hybrids. Muttonni et al. [28] also reported significant differences in glucose and pentose levels across internodes within the same plant. This within plant variability likely contributes to the frequently observed high variability of glucose and pentose levels in whole-plant stover samples. More importantly regarding stover ethanol yield potential, hybrid was not found to have a significant effect on hydrolysable xylan and glucan levels and subsequent estimated ethanol yield. The two hybrids studied are representative of US Midwest commercially available corn grain hybrids. Nonetheless, the experimental limitation of two hybrids makes it difficult to draw a comprehensive conclusion regarding hybrid effect on corn stover ethanol quality component levels. Corn hybrid also had a significant interaction with location (Table 7). At the Mason location, the Nutech hybrid had a significantly higher stover hydrolysable glucan level than the Bayside hybrid. However, at the other locations there was no significant difference and hybrid did not ultimately have a significant effect on estimated stover ethanol yield ( $\mathrm{g} \mathrm{EtOH} \mathrm{g}^{-1}$ stover dry matter). 
There was a significant location x year interaction (Table 4) for estimated corn stover ethanol yield $\left(\mathrm{g} \mathrm{g}^{-1}\right)$. In 2010, stover harvested at the Mason location produced an estimated ethanol yield potential of $0.17 \mathrm{~g} \mathrm{~g}^{-1}$ which was not significantly different from the poorest quality stover for that year (Table 8). Conversely, in 2011, the same Mason location produced corn stover with an estimated ethanol yield potential $\left(0.19 \mathrm{~g} \mathrm{~g}^{-1}\right)$ equal to the best locations. Opposite to the Mason location results, the Ingham location in 2010, produced corn stover among the highest in terms of estimated ethanol yield at $0.19 \mathrm{~g} \mathrm{~g}^{-1}$ while the 2011 stover quality was low relative to the other locations. The significant location by year interaction for estimated ethanol yield, combined with the significant location effect on many of the corn stover ethanol quality components suggests that environment plays an important role on overall corn stover quality for ethanol production.

Ethanol yield on a land area basis $\left(1 \mathrm{ha}^{-1}\right)$ was affected by hybrid pair, location and the location by year interaction (Table 4). These same factors were found to have a significant effect on corn grain yield $\left(\mathrm{Mg} \mathrm{ha}^{-1}\right)$. The close relationship observed between corn grain yield and stover ethanol yield $\left(1 \mathrm{ha}^{-1}\right)$ is due to the reported 1:1 mass ratio of corn grain to corn stover [9, 10], and thus potential stover ethanol yield on a land area basis would be expected to have a direct correlation with grain yield. Similarly, the higher grain yielding hybrid (Table 6) also had a significantly higher stover ethanol yield on a land area basis. This study assumed $50 \%$ of the total corn stover was harvested, a level achievable with conventional forage baling equipment available to most farmers (11). The environmental and agronomic benefits of retaining some of the stover on the field have been documented [29] and need to be considered on a field by field basis when determining the amount of stover to harvest. 
Similar to our findings with corn stover, Hao et al., in 2010 [30] had reported high spatial variability in corn grain ethanol yield on a $\mathrm{g} \mathrm{g}^{-1}$ basis. Interestingly, our results suggest a negative correlation between corn stover estimated ethanol yield $\left(\mathrm{g} \mathrm{g}^{-1}\right)$ and corn grain yield $(\mathrm{Mg}$ $\left.\mathrm{ha}^{-1}\right)$. The estimated corn stover ethanol yield location $\mathrm{x}$ year interaction observed for the Mason and Ingham locations was the exact opposite of the interaction observed for corn grain yield (Table 8). In 2010, the Mason location produced high corn grain yields of $14.3 \mathrm{Mg} \mathrm{ha}^{-1}$ and poor ethanol quality stover with an estimated stover ethanol yield potential of $0.17 \mathrm{~g} \mathrm{~g}^{-1}$. Conversely, in 2011, the same Mason location produced significantly lower corn grain yields of $13.8 \mathrm{Mg} \mathrm{ha}^{-1}$ and a significantly higher corn stover estimated ethanol yield potential $\left(0.19 \mathrm{~g} \mathrm{~g}^{-1}\right)$. And, at the Ingham location, 2010 grain yields were relatively poor at $10.5 \mathrm{Mg} \mathrm{ha}^{-1}$ with a relatively high corn stover estimated ethanol yield of $0.19 \mathrm{~g} \mathrm{~g}^{-1}$. Consistently, the 2011 Ingham corn grain yields were relatively higher at $13.7 \mathrm{Mg} \mathrm{ha}^{-1}$ with a somewhat lower estimated stover ethanol yield $\left(0.185 \mathrm{~g} \mathrm{~g}^{-1}\right)$ relative to the 2010 level.

The negative correlation between corn grain yield $\left(\mathrm{Mg} \mathrm{ha}^{-1}\right)$ and stover ethanol yield ( $\mathrm{g} \mathrm{g}$ ${ }^{1}$ ) is indicative of a source-sink relationship regarding the partitioning of available assimilates between grain and stover [31]. Regression analysis results (Fig 2,) further support the proposed source-sink relationship. The regression response of estimated ethanol yield $\left(\mathrm{g} \mathrm{g}^{-1}\right)$ relative to corn grain yield $\left(\mathrm{Mg} \mathrm{ha}^{-1}\right)$ is significant at $\mathrm{P}=0.0001$ with an $R^{2}$ coefficient of 0.17 . The $R^{2}$ coefficient may seem somewhat low, but can be rationalized by the inherent high variability of an environment based $\mathrm{x}$ plant physiological based interaction response, and a relatively large number $(\mathrm{N}=104)$ of complex micro-environments. Because of the generally positive correlation 
between corn grain yield and corn stover yield on a mass to mass ratio $[9,10]$, a decrease in stover quality on a $\mathrm{g} \mathrm{g}^{-1}$ basis associated with a high grain yield, would be offset by an expected increase in the total stover produced on a $\mathrm{Mg} \mathrm{ha}^{-1}$ basis. Our data (Table 8) showed a 35\% difference in potential total stover yield $\left(\mathrm{Mg} \mathrm{ha}^{-1}\right)$ compared to a $18 \%$ difference in stover ethanol yield $\left(\mathrm{g} \mathrm{g}^{-1}\right)$ between the best and worst performing locations, which clearly demonstrates that quantity of stover produced is more critical than quality of stover produced for achieving high stover ethanol yields on a land area basis. Nevertheless, a stover feedstock with $18 \%\left(\mathrm{~g} \mathrm{~g}^{-1}\right)$ greater ethanol conversion efficiency would be preferable from the perspective of the biorefinery. Environmental conditions favoring vegetative growth in the early growing season (large source), combined with poor environmental conditions during pollination or the grain filling season (small sink) would likely result in a stover having a higher $\mathrm{g} \mathrm{g}^{-1}$ ethanol conversion.

\section{Conclusions}

The presence of the Bt Cry $1 \mathrm{AB} \&$ mCry 3 transgene in corn stover did not affect the concentration of the important ethanol quality components glucose and xylose and did not affect stover lignin levels or bioethanol quality on $\mathrm{g} \mathrm{g}^{-1}$ basis. Consistent with the high variability in corn stover composition found in the literature, we found location had a significant effect on stover analytical components xylose, glucose, hydrolysable xylan, hydrolysable glucan, and lignin. On a land area basis, potential stover ethanol yield $\left(\mathrm{ha}^{-1}\right)$ tracked closely with corn grain yield (Mg ha-1). However, an inverse relationship between corn grain yield $\left(\mathrm{Mg} \mathrm{ha}^{-1}\right)$ and estimated stover ethanol yield $\left(\mathrm{g} \mathrm{g}^{-1}\right)$ was observed, suggesting a source-sink relationship regarding the partitioning of available assimilates between grain and stover. Nevertheless, the 
quantity of stover produced was found to be more critical than the quality of stover produced in maximizing potential stover ethanol yield on a land area basis.

\section{Acknowledgements}

This research was funded by the Great Lakes Bioenergy Resource Center (DOE Office of Science BER DE-FC02-07ER64494) and Michigan State University, AgBioResearch. We thank William Widdicombe and Lori Williams for their help in the field plots. We also thank Charles Donald for helping us perform AFEX pretreatment, Nirmal Uppugundla for helping us with Fermentation experiment, Cliff Foster for helping us with the lignin composition and the MSU soil and plant nutrient laboratory for the soil data. 


\section{References}

[1] Atchinson JE, Hettenhaus JR. Innovative methods for corn stover collecting, handling, storing and transporting (No. NREL/SR-510-33893). National renewable energy lab golden Co. 2004.

[2] Sokhansanj S, Turhollow A, Cushman J, Cundiff J. Engineering aspects of collecting corn stover for bioenergy. Biomass and Bioenergy 2002; 23: 347-355.

[3] Wilhelm WW, Johnson JMF, Hatfield JL, Voorhees WB, Linden DR. Crop and soil productivity response to corn residue removal. American society of Agronomy 2004; Vol. 96 (1), 1-17.

[4] Himmel ME, Ding SY, Johnson DK, Adney WS, Nimlos MR, Brady JW, Foust TD. Biomass recalcitrance: engineering plants and enzymes for biofuels production. Science 2007; 315 (5813), 804-7.

[5] Ragauskas AJ, Williams CK, Davison BH, Britovsek G, Cairney J, Eckert CA, et al. The path forward for biofuels and biomaterials. Science 2006; 311(5760);484-9.

[6] Sluiter JB, Ruiz RO, Scarlata CJ, Sluiter AD, Templeton DW. Compositional analysis of lignocellulosic feed stocks. 1. Review and descriptions of methods. J Agric Food Chem. 2010; August 25; 58(16): 9043-9053. 
[7] Farrell AE, Plevin RJ, Turner BT, Jones AD, O'Hare M, Kammen DM. Ethanol can contribute to energy and environmental goals. Science, 2006; 311:506-8.

[8] Moniruzzaman M, Oien BS, Skory CO, Chen ZO, Hespell RB, Ho NWY, Dale BE, et al. Fermentation of corn fibre sugars by an engineered xylose utilizing Saccharomyces yeast strain. World Journal of Microbiology \& Biotechnology 1997; 13:341-6.

[9] Tollenaar M, Deen W, Echarte L, Lu W. Effect of crowding stress on dry matter accumulation and harvest index in maize. Agron. J. 2006; Vol. 98:930-7.

[10] Graham RL, Nelson R, Sheehan J, Perlack RD, Wright LL. Current and potential U.S. corn stover supplies. Agron J. 2007; 99:1-11.

[11] Shinners KJ, Binversie BN, Muck RE, Weimer PJ. Comparison of wet and dry corn stover harvest and storage. Biomass and Bioenergy 2007; 31:211-221.

[12] Templeton DW, Sluiter AD, Hayward TK, Hames BR, Thomas SR. Assessing corn stover composition and sources of variability via NIRS. Cellulose 2009; 16 (4), 621-639.

[13] Banerjee G, Car S, Scott-Craig JS, Borrusch MS, Aslam N, Walton JD. Synthetic enzyme mixtures for biomass deconstruction: production and optimization of a core set. Biotechnol. Bioengineer 2010; 106:707-720. 
[14] United States Departement of Agriculture (USDA), National Agricultural Statistics Service (NASS) June 2013; Acreage Report ISSN: 1949-1522. http://usda01.library.cornell.edu/usda/current/Acre/Acre-06-28-2013.pdf.

[15] Lynch RE. European corn borer: yield losses in relation to hybrid and stage of corn development. Journal of Economic Entomology 1980; 73:159-164.

[16] Saxena D, Stotzky G. Bt corn has a higher lignin content than non-Bt corn. American Journal of Botany 2001; 88(9):1704-6.

[17] Thelen KD, Widdicombe WD, Williams L. Michigan Corn Hybrids Compared. Michigan State University Extension Bulletin E-431, p. 43, 2011.

[18] Sluiter A, Ruiz R, Scarlata C, Sluiter J, Templeton D. Determination of extractives in biomass. Laboratory Analytical Procedure (LAP) 1617, 2005.

[19] Sluiter A, Hames B, Ruiz R, Scarlata C, Sluiter J, Templeton D, Crocker D. Determination of structural carbohydrates and lignin in biomass. Laboratory Analytical Procedure, 2008.

[20] Foster CE, Martin TM, Pauly M. Comprehensive Compositional Analysis of Plant Cell Walls (Lignocellulosic biomass) Part I: Lignin. JoVE 37, 2010. 
[21] Bals B, Rogers C, Jin M, Balan V, Dale BE. Evaluation of ammonia fibre expansion (AFEX) pretreatment for enzymatic hydrolysis of switch grass harvested in different seasons and locations. Biotechnology for Biofuels 2010; 3:1.

[22] Lau MW, Dale BE. Cellulosic ethanol production from AFEX-treated corn stover using Saccharomyces cerevisiae 424A (LNH-ST). PNAS 2009; Vol. 106. No. 5.

[23] Jin M, Gunawan C, Balan V, Lau MW, Dale BE. Simultaneous saccharification and cofermentation (SSCF) of AFEXTM pretreated corn stover for ethanol production using commercial enzymes and Saccharomyces cerevisiae 424A(LNH-ST). Bioresource Technology 2012; 110:587-594.

[24] Banerjee G, Scott-Craig JS, Walton JD. Improving enzymes for biomass conversion: A basic research perspective. Bioenergy Research 2010; 3:82 - 92.

[25] Faust MA. Research update on Bt corn silage. In Proceedings of the Four-State Applied Nutrition and Management Conference. MWPS-4SD5. Iowa State University, Ames, Iowa, USA. 1999.

[26] Kadam KL, McMillan JD. Availability of corn stover as a sustainable feedstock for bioethanol production. Bioresource Technology 2003; 88(1), 17-25. 
[27] Lewis MF, Lorenzana RE, Jung HJG, and Bernardo R. Potential for simultaneous improvement of corn grain yield and stover quality for cellulosic ethanol. Crop Science 2010; Vol. 50, No. 2:516-523.

[28] Muttoni G, Johnson JM, Santoro N, Rhiner CJ, von Mogel KJ, Kaeppler SM, de Leon, N. A high-throughput core sampling device for the evaluation of maize stalk composition. Biotechnology for Biofuels. 2012; 5:27

[29] Mann L, Tolbert V, Cushman J. Potential environmental effects of corn (Zea mays L.) stover removal with emphasis on soil organic matter and erosion. Agriculture, Ecosystems \& Environment. 2002; 89:149-166

[30] Hao X, Thelen KD, Gao J. Effects of soil and topographic properties on spatial variability of corn grain ethanol yield. Agron J. 2010; 102:998-1006.

[31] Schoper JB, Johnson RR, Lambert RJ. Maize yield response to increased assimilates supply. Crop Sci. 1982; 22:1184-9. 
Table 1. Hybrid name, Bt traits, location, and year grown, for the corn stover analyzed in the experiment.

\begin{tabular}{|c|c|c|c|c|}
\hline \multirow[t]{2}{*}{ Isoline } & \multirow[t]{2}{*}{$\mathrm{RM}^{\mathrm{e}}$} & \multirow[t]{2}{*}{ Bt trait } & \multicolumn{2}{|c|}{ Location (County, MI) } \\
\hline & & & 2010 & 2011 \\
\hline Nutech 2A 804 & 104 & No & $\begin{array}{l}\text { Ingham, Saginaw, } \\
\text { Menominee }\end{array}$ & $\begin{array}{c}\text { Ingham, Saginaw, Mason, } \\
\text { Menominee }\end{array}$ \\
\hline $\begin{array}{c}\text { Nutech } 5 \mathrm{~N} 804 \\
\left(\mathrm{GT}^{\mathrm{a}} / \mathrm{CB}^{\mathrm{b}} / \mathrm{LL}^{\mathrm{c}} / \mathrm{RW}^{\mathrm{d}}\right)\end{array}$ & 104 & $\begin{array}{l}\text { Cry1AB, } \\
\text { mCRY3 }\end{array}$ & $\begin{array}{l}\text { Ingham, Saginaw, } \\
\text { Menominee }\end{array}$ & $\begin{array}{c}\text { Ingham, Saginaw, Mason, } \\
\text { Menominee }\end{array}$ \\
\hline Bayside 4090 & 90 & No & Mason, Menominee & $\begin{array}{c}\text { Ingham, Saginaw, Mason, } \\
\text { Menominee }\end{array}$ \\
\hline $\begin{array}{c}\text { Bayside } 3090 \\
\left(\mathrm{GT}^{\mathrm{a}} / \mathrm{CB}^{\mathrm{b}} / \mathrm{LL}^{\mathrm{c}}\right)\end{array}$ & 90 & Cry1AB & Mason, Menominee & $\begin{array}{c}\text { Ingham, Saginaw, Mason, } \\
\text { Menominee }\end{array}$ \\
\hline
\end{tabular}

${ }^{\mathrm{a}} \mathrm{GT}$ : Glyphosate Tolerant.

${ }^{\mathrm{b}} \mathrm{CB}$ : Corn Borer control.

${ }^{c}$ LL: Liberty Link (Glufosinate tolerance).

${ }^{\mathrm{d}} \mathrm{RW}$ : Root Worm control.

RM: Relative Maturity. 
Table 2. Soil type and nutrient amounts calculated in Parts Per Million (PPM) of the four locations studied in Michigan for this study.

\begin{tabular}{|c|c|c|c|c|c|c|c|c|c|c|c|}
\hline Location & Soil Type & \multicolumn{5}{|c|}{2010 soil conditions (PPM) } & \multicolumn{5}{|c|}{2011 soil conditions (PPM) } \\
\hline & & $\mathrm{pH}$ & $\mathrm{P}^{\mathrm{a}}$ & $\mathrm{K}^{\mathrm{b}}$ & $\mathrm{Ca}^{\mathrm{c}}$ & $\mathrm{Mg}^{\mathrm{d}}$ & $\mathrm{pH}$ & $\mathrm{P}^{\mathrm{a}}$ & $\mathrm{K}^{\mathrm{b}}$ & $\mathrm{Ca}^{\mathrm{c}}$ & $\mathrm{Mg}^{\mathrm{d}}$ \\
\hline Ingham & Capac Loam & 7.3 & 59 & 142 & 1924 & 248 & 6 & 50 & 145 & 1615 & 247 \\
\hline Mason & $\begin{array}{l}\text { Fern-Marlette } \\
\text { Complex }\end{array}$ & 6.7 & 100 & 163 & 861 & 140 & 6.1 & 154 & 154 & 731 & 86 \\
\hline Menominee & $\begin{array}{l}\text { Onaway } \\
\text { Sandy Loam }\end{array}$ & 7.1 & 13 & 64 & 1401 & 247 & 7.4 & 19 & 62 & 1185 & 193 \\
\hline Saginaw & SGSP Loam ${ }^{\mathrm{e}}$ & 6.2 & 90 & 207 & 818 & 165 & 6.6 & 28 & 80 & 1282 & 256 \\
\hline
\end{tabular}

${ }^{\mathrm{a}}$ Phosphorous.

${ }^{\mathrm{b}}$ Potassium.

${ }^{\mathrm{c}}$ Calcium.

${ }^{\mathrm{d}}$ Magnesium.

e Shiawassee Gravelly Sandy and Parkhill Loam. 
Table 3. Planting, harvesting dates and fertilizer application rates [Nitrogen $(\mathrm{N})$, Phosphorous $(\mathrm{P})$ and Potassium (K) in kg ha ${ }^{-1}$ ] in 2010 and 2011 at the four experimental locations.

\begin{tabular}{|c|c|c|c|c|}
\hline \multirow[b]{2}{*}{ Location } & \multirow[b]{2}{*}{ Year } & \multicolumn{2}{|c|}{ Date } & \multirow{2}{*}{$\begin{array}{l}\text { Fertilizer } \\
\mathrm{N}-\mathrm{P}-\mathrm{K}\end{array}$} \\
\hline & & Planted & Harvested & \\
\hline & & \multicolumn{2}{|c|}{$(\mathrm{mm} / \mathrm{dd} / \mathrm{yy})$} & $\left(\mathrm{kg} \mathrm{ha}^{-1}\right)$ \\
\hline Ingham & 2010 & $05 / 10 / 10$ & $10 / 18 / 10$ & $212.8-8.96-125.44$ \\
\hline Ingham & 2011 & 06/06/11 & $10 / 26 / 11$ & $212.8-8.96-125.44$ \\
\hline Mason & 2010 & $05 / 16 / 10$ & $10 / 25 / 10$ & $171.36-8.96-2.24$ \\
\hline Mason & 2011 & $05 / 16 / 11$ & $11 / 03 / 11$ & $181.44-33.6-34.72$ \\
\hline Menominee & 2010 & $05 / 19 / 10$ & $11 / 01 / 10$ & $108.64-8.96-2.24$ \\
\hline Menominee & 2011 & $05 / 25 / 11$ & $11 / 07 / 11$ & $138.88-33.6-34.72$ \\
\hline Saginaw & 2010 & $05 / 05 / 10$ & $10 / 12 / 10$ & $171.36-8.96-2.24$ \\
\hline Saginaw & 2011 & $05 / 13 / 11$ & $11 / 01 / 11$ & $181.44-33.6-34.72$ \\
\hline
\end{tabular}


Table 4. Summary of ANOVA for corn stover quality component levels and yields as affected by hybrid, Bt trait, and location per gram of stover dry matter in the years 2010 and 2011.

\begin{tabular}{|c|c|c|c|c|c|c|c|c|c|}
\hline Effect & DF & Xylose & $\begin{array}{c}\text { Xylan } \\
\text { conversion }\end{array}$ & Glucose & $\begin{array}{c}\text { Glucan } \\
\text { conversion }\end{array}$ & Lignin & $\begin{array}{c}\text { Estimated } \\
\text { EtOH } \\
\text { yield } \\
\end{array}$ & $\begin{array}{l}\text { Corn } \\
\text { grain } \\
\text { yield } \\
\end{array}$ & $\begin{array}{c}\text { Estimated } \\
\text { EtOH } \\
\text { yield } \\
\end{array}$ \\
\hline & & & & 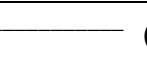 & $\left.\mathrm{g}^{-1}\right)$ & & & $\left(\mathrm{Mg} \mathrm{ha}^{-1}\right)$ & $\left(1 \mathrm{ha}^{-1}\right)$ \\
\hline $\mathrm{Bt}$ & 1 & NS & NS & NS & NS & NS & NS & NS & NS \\
\hline Hybrid pair & 1 & NS & NS & $* *$ & NS & $* * *$ & NS & $* *$ & $* *$ \\
\hline $\begin{array}{l}\text { Bt } x \text { hybrid } \\
\text { pair }\end{array}$ & 1 & NS & NS & NS & NS & NS & NS & NS & NS \\
\hline Location & 3 & $* *$ & $* *$ & $* * *$ & $* * *$ & $*$ & NS & $* * *$ & $* *$ \\
\hline $\begin{array}{l}\text { Hybrid pair } \\
\mathrm{x} \text { Location } \\
\mathrm{Bt} \mathrm{x}\end{array}$ & 3 & NS & NS & NS & $*$ & NS & NS & NS & NS \\
\hline $\begin{array}{l}\text { Location } \\
\text { Location } \mathrm{x}\end{array}$ & 3 & NS & NS & NS & NS & NS & NS & NS & NS \\
\hline Year & 3 & NS & NS & NS & NS & NS & $*$ & $* * *$ & $* *$ \\
\hline Replication & 3 & NS & NS & NS & NS & NS & NS & NS & NS \\
\hline Year & 1 & NS & NS & NS & NS & NS & NS & NS & NS \\
\hline Bt x Year & 1 & NS & NS & NS & NS & NS & NS & NS & NS \\
\hline
\end{tabular}

* Significant at the 0.05 probability level.

** Significant at the 0.01 probability level.

*** Significant at the 0.001 probability level.

NS, not significant. 
Table 5. Composition analyses per gram of corn stover dry matter harvested at the indicated locations. Data are combined across 2010 and 2011.

\begin{tabular}{|c|c|c|c|c|c|c|c|c|c|c|}
\hline Location & Xylose & & $\begin{array}{c}\text { Hydrolysable } \\
\text { xylan }\end{array}$ & & Glucose & & $\begin{array}{c}\text { Hydrolysable } \\
\text { glucan }\end{array}$ & & Lignin & \\
\hline Ingham & 0.176 & $\mathrm{~b}$ & 0.796 & $a b$ & 0.355 & e & 0.714 & $\mathrm{a}$ & 0.214 & $\mathrm{a}$ \\
\hline Mason & 0.176 & $\mathrm{~b}$ & 0.819 & $\mathrm{a}$ & 0.328 & b & 0.740 & $\mathrm{a}$ & 0.210 & $a b$ \\
\hline Menominee & 0.191 & $\mathrm{a}$ & 0.787 & $a b$ & 0.365 & $\mathrm{a}$ & 0.660 & $\mathrm{~b}$ & 0.214 & $\mathrm{a}$ \\
\hline Saginaw & 0.183 & $a b$ & 0.762 & $\mathrm{~b}$ & 0.353 & $\mathrm{a}$ & 0.752 & $\mathrm{a}$ & 0.206 & $\mathrm{~b}$ \\
\hline
\end{tabular}

Means followed by the same letter are not significantly different $\mathrm{p}=0.05$. 
Table 6. Hybrid effect on corn stover glucose $\left(\mathrm{g} \mathrm{g}^{-1}\right)$, lignin $\left(\mathrm{g} \mathrm{g}^{-1}\right)$, corn grain yield $\left(\mathrm{Mg} \mathrm{ha}^{-1}\right)$, and ethanol yield $\left(1 \mathrm{ha}^{-1}\right)$. Data are combined across 2010 and 2011.

\begin{tabular}{|c|c|c|c|c|c|c|c|c|}
\hline Hybrid & & & Lignin & & $\begin{array}{l}\text { Corn } \\
\text { grain } \\
\text { yield }\end{array}$ & \multicolumn{3}{|c|}{$\begin{array}{l}\text { Ethanol } \\
\text { yield }\end{array}$} \\
\hline & \multicolumn{4}{|c|}{$\stackrel{\text { Glucose }}{-}\left(\mathrm{g} \mathrm{g}^{-1}\right)-$} & $\left(\mathrm{Mg} \mathrm{ha}^{-1}\right)$ & & $\left(1 \mathrm{ha}^{-1}\right)$ & \\
\hline Bayside & 0.358 & $\mathrm{a}$ & 0.215 & $\mathrm{a}$ & 12.1 & b & 1380 & $\mathrm{~b}$ \\
\hline Nutech & 0.343 & $b$ & 0.208 & $\mathrm{~b}$ & 13.8 & $\mathrm{a}$ & 1566 & $\mathrm{a}$ \\
\hline
\end{tabular}


Table 7. Hybrid $\mathrm{x}$ location effect on corn stover hydrolysable glucan levels per gram of stover dry matter. Data are combined across 2010 and 2011.

\begin{tabular}{cccc}
\hline Hybrid & Location & $\begin{array}{c}\text { Hydrolysable glucan } \\
\left(\mathrm{g} \mathrm{g}^{-1}\right)\end{array}$ \\
\hline Bayside & Ingham & 0.729 & $\mathrm{ab}$ \\
Nutech & Ingham & 0.698 & $\mathrm{~b}$ \\
Bayside & Mason & 0.706 & $\mathrm{~b}$ \\
Nutech & Mason & 0.774 & $\mathrm{a}$ \\
Bayside & Menominee & 0.651 & $\mathrm{c}$ \\
Nutech & Menominee & 0.669 & $\mathrm{bc}$ \\
Bayside & Saginaw & 0.734 & $\mathrm{a}$ \\
Nutech & Saginaw & 0.771 & $\mathrm{a}$ \\
\hline
\end{tabular}

Means followed by the same letter are not significantly different $\mathrm{p}=0.05$. 
Table 8. Location $\mathrm{x}$ year effect on estimated stover ethanol yield $\left(\mathrm{g} \mathrm{g}^{-1}\right)$, corn grain yield $\left(\mathrm{Mg} \mathrm{ha}^{-}\right.$ $\left.{ }^{1}\right)$, and estimated stover ethanol yield ( $\left(\mathrm{ha}^{-1}\right)$.

\begin{tabular}{|c|c|c|c|c|c|c|c|}
\hline \multirow{2}{*}{$\frac{\text { Location }}{\text { Ingham }}$} & \multirow{2}{*}{$\frac{\text { Year }}{2010}$} & \multicolumn{2}{|c|}{$\begin{array}{c}\text { Estimated } \\
\text { stover EtOH } \\
\text { yield } \\
\left(\mathrm{g} \mathrm{g}^{-1}\right) \\
\end{array}$} & \multicolumn{2}{|c|}{$\begin{array}{l}\text { Corn } \\
\text { grain } \\
\text { yield } \\
\left(\mathrm{Mg} \mathrm{ha}^{-1}\right) \\
\end{array}$} & \multirow{2}{*}{$\begin{array}{c}\text { Estimated } \\
\text { stover EtOH } \\
\text { yield } \\
\left(1 \mathrm{ha}^{-1}\right) \\
1258\end{array}$} & \\
\hline & & 0.190 & $a b c$ & 10.5 & $\mathrm{c}$ & & b \\
\hline Ingham & 2011 & 0.185 & $\mathrm{bc}$ & 13.7 & $\mathrm{~b}$ & 1490 & b \\
\hline Mason & 2010 & 0.172 & d & 14.3 & $\mathrm{a}$ & 1547 & $\begin{array}{l}\mathrm{a} \\
\mathrm{b}\end{array}$ \\
\hline Mason & 2011 & 0.195 & $a b$ & 13.8 & b & 1598 & $\begin{array}{l}\mathrm{a} \\
\mathrm{b}\end{array}$ \\
\hline Menominee & 2010 & 0.174 & $\mathrm{~cd}$ & 16.1 & $\mathrm{a}$ & 1767 & $\mathrm{a}$ \\
\hline Menominee & 2011 & 0.199 & $\mathrm{a}$ & 11.9 & c & 1406 & b \\
\hline Saginaw & 2010 & 0.183 & bcd & 12.1 & bc & 1391 & b \\
\hline Saginaw & 2011 & 0.201 & $\mathrm{a}$ & 11.2 & $\mathrm{c}$ & 1327 & b \\
\hline
\end{tabular}

Means followed by the same letter are not significantly different $\mathrm{p}=0.05$. 


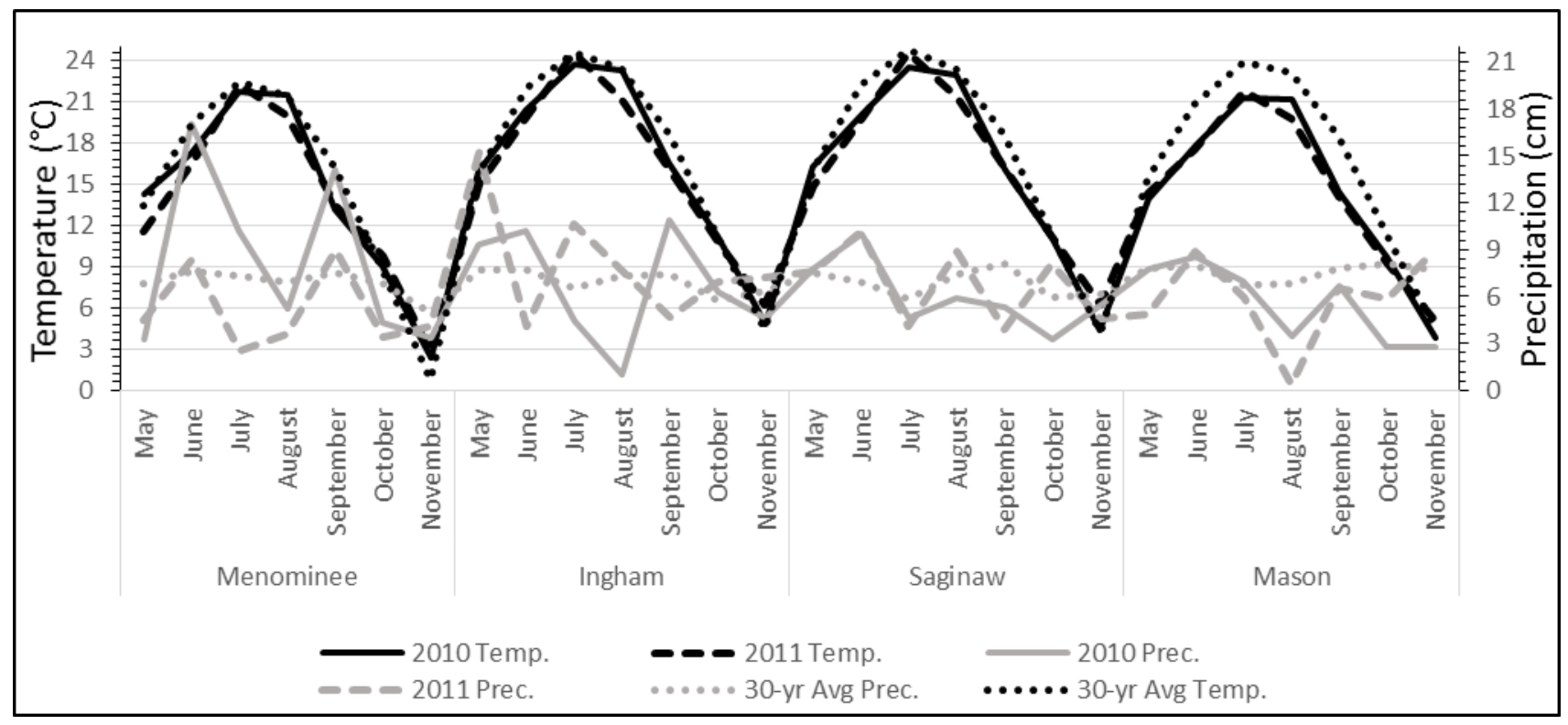

Figure 1. Mean temperatures and precipitation obtained from NOAA for the study years compared to the 30 -year means $(1983$ - 2012) for the four locations studied in Michigan. 


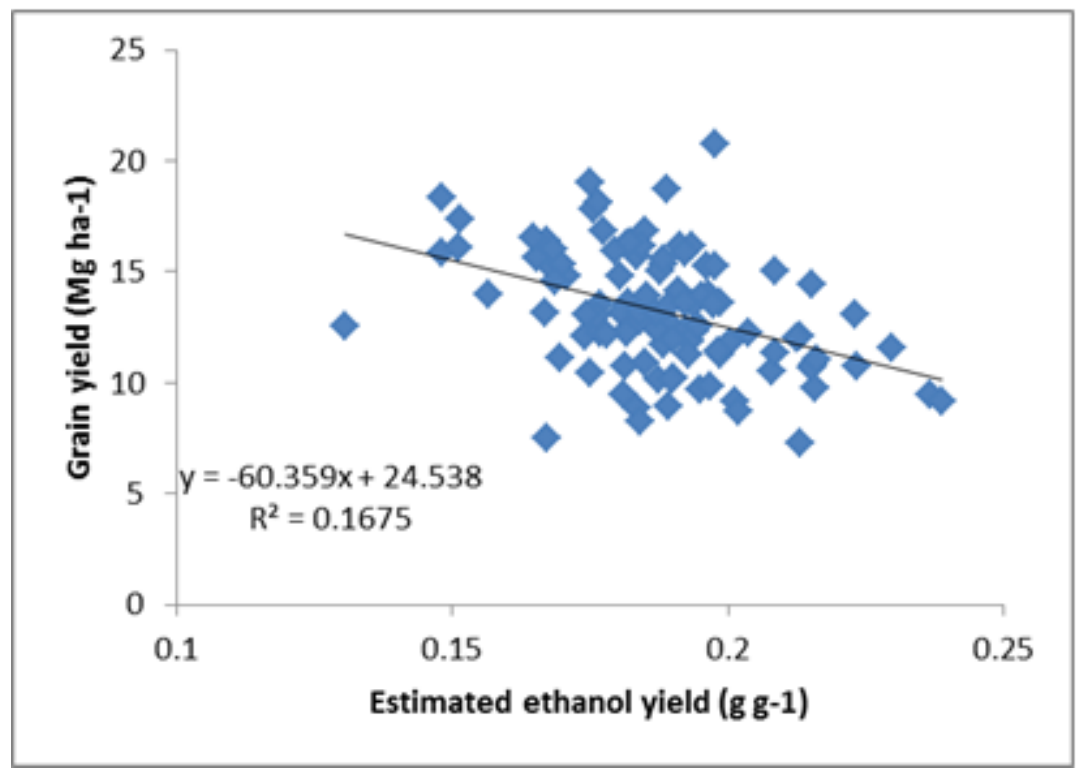

Figure 2. Regression analyses for estimated corn stover ethanol yield $\left(\mathrm{g} \mathrm{g}^{-1}\right)$ relative to corn grain yield ( $\left.\mathrm{Mg} \mathrm{ha}^{-1}\right)$. The linear regression equation: $\mathrm{y}=-60 \mathrm{x}+24.5$ and $\mathrm{R}^{2}=0.17$. The calculated regression $F$ value was significant $(P=0.0001)$. 